\title{
TLC Profile and Activity Test of Secondary Metabolites Aspergillus flavus "In-Habiting" Queen Termite's Nest Macrotermes gilvus on Enriched Media
}

\author{
Yohannes Alen*, Rezki Amelia, Akmal Djamaan
}

Faculty of Pharmacy, Universitas Andalas, Limau manis, Padang, 25163, Indonesia

Submitted 29 November 2017; Revised 12 January 2018; Accepted 30 January 2018; Published 05 February 2018

*Corresponding author: yohannesalen@yahoo.co.id

\begin{abstract}
Previous study had succesfully screened four types of fungus lived in queen termite's nest, including Aspergillus flavus. This fungus produced phenolic compound on SDA media which only existed in first and second subculture extract, faded gradually on the next culture. Therefore, enrichment of media by using queen termite nest in order to know the phenolic metabolite compound can be reformed or else, forming a new metabolite compounds. The enrichment was done by using four different media concentrations $(0.25 ; 0.50 ; 0.75$ and $1 \mathrm{~g} / \mathrm{mL})$. The results showed that enrichment of $1 \mathrm{~g} / \mathrm{mL}$ provided the most optimum fungus growth. The third subculture of Aspergillus flavus was bred on enriched media which would become the fourth subculture, this fungus was bred until the tenth subculture, and then the extraction and fracination to each culture was carried out. Based on TLC profile using chloroform : methanol (9:1) as mobile phase, phenolic metabolite compound didn't formed until the tenth subculture yet, but six new spots terpenoid compounds were formed. The result of columns chromatography obtained 10 sub-fraction. The activity test of antibiotic was done by diffusion method against 12 bacteria and 3 fungus test. Stain spot 2, 5, $6(\operatorname{Rf} 0.84 ; 0.36 ; 0.26)$ could inhibit the growth of Pseudomonas aeruginosa ATCC 27853, stain spot 3 and 4 ( Rf $0.74 ; 0.52$ ) inhibit the growth of Micrococcus luteus ATCC 10240.
\end{abstract}

Keywords: Activity Assay, Aspergillus flavus, Enriched media, Macrotermes gilvus Hagen, Secondary metabolites, TLC Profiles

\section{Profil KLT dan Uji Aktivitas Metabolit Sekunder Aspergillus flavus "In- Habiting" Sarang Ratu Termite Macrotermes gilvus pada Media Diperkaya}

\begin{abstract}
Abstrak
Peneliti terdahulu telah berhasil menapis empat jamur yang hidup disarang ratu termite Macrotermes gilvus Hagen., termasuk Aspergillus flavus. Jamur ini bertahan menghasilkan senyawa metabolit golongan fenol pada media SDA hanya pada ekstrak subkultur biakan pertama dan kedua, berangsur hilang pada biakan berikutnya. Oleh karena itu dilakukan pengayaan media dengan bahan sarang ratu termite yang bertujuan untuk mengetahui apakah senyawa metabolit golongan fenol dapat kembali terbentuk atau justru membentuk senyawa metabolit baru. Pengayaan dilakukan menggunakan empat konsentrasi media berbeda $(0,25 ; 0,50 ; 0,75$ dan $1 \mathrm{~g} / \mathrm{mL})$. Hasil yang diperoleh menunjukkan pengayaan media SDA dengan sarang $1 \mathrm{~g} / \mathrm{mL}$ memberikan pertumbuhan jamur paling optimal. Jamur subkultur biakan ketiga dibiakkan pada media dan menjadi biakan keempat. jamur dibiakkan hingga subkultur kesepuluh, dilakukan ekstraksi dan fraksinasi terhadap masing-masing biakan. Berdasarkan analisis profil KLT fraksi etil asetat jamur dengan fase gerak kloroform : metanol (9:1), senyawa fenol belum terbentuk hingga subkultur kesepuluh, namun terbentuk 6 noda baru golongan terpenoid. Hasil kromatografi kolom didapatkan 10 sub-fraksi. Uji aktivitas dilakukan dengan metode difusi terhadap 12 bakteri uji dan 3 jamur uji. Noda 2, 5, dan 6 (Rf 0,$84 ; 0,36 ; 0,26)$ diduga menghambat pertumbuhan Pseudomonas aeruginosa ATCC 27853 , noda 3 , dan 4 ( Rf 0,$74 ; 0,52$ ) diduga menghambat pertumbuhan Micrococcus luteus ATCC 10240.
\end{abstract}

Kata kunci: Aspergillus flavus, Macrotermes gilvus Hagen, Media yang diperkaya, Metabolisme Sekunder, Profil TLC, Uji Aktivitas 


\section{Pendahuluan}

Metabolit sekunder merupakan senyawa hasil metabolisme makhluk hidup yang tidak terlalu berperan penting dalam pertumbuhan makhluk hidup tersebut, namun beperan sebagai pelindung bagi penghasilnya, dan umumnya dihasilkan dalam jumlah yang sedikit. Senyawa metabolit sekunder telah banyak dimanfaatkan, salah satunya sebagai antibiotik. Antibiotik dihasilkan oleh mikroorganisme terutama jamur, salah satu sumber jamur yang menarik adalah jamur yang hidup pada sarang ratu termite Macrotermes gilvus Hagen.

Termite (rayap) merupakan salah satu ordo yang tergabung dalam kelas Hexapoda dari filum Arthropoda. Didalam bahasa Minang, rayap dikenal dengan nama "Anai-anai". Termite sangat mudah ditemukan diberbagai ekosistem, hutan, pertanian, perkebunan, dan juga ditemukan pada ekosistem pemukiman atau perkotaan ${ }^{1}$. Termite merupakan dekomposer penting dalam pembentukan tanah ${ }^{2}$.

Ratu termite mengandung protein total $43,55 \%$, karbohidrat total $23,44 \%$, lemak total $23,31 \%$, kadar abu $6,99 \%$ dan kadar air $1,22 \%^{3}$. Kandungan asam amino esensial tertinggi pada ratu termite adalah Lysin (39013,74 ppm), terendah adalah Tryptopan $(3560.64)^{4}$. Kandungan asam lemak pada ratu termite adalah Omega-9 (32,81\%), Omega-6 $(0,34 \%)$, dan Omega-3 $(0,07 \%)^{5,6}$. Ratu termite telah digunakan di beberapa negara sebagai makanan dan obat tradisional serta sebagai suplemen kesehatan ${ }^{7,8}$. Ratu termite juga dapat dijadikan sebagai imunomodulator, obat luka bakar, dan dapat menjaga kadar lemak tubuh. Studi toksisitas akut dan subakut menunjukkan ratu termite tidak toksik terhadap organ hati ${ }^{9,4,6,10}$. Masyarakat Nigeria mengkonsumsi ratu termite Macroterme bellicosus karena nilai protein dan lemak kasarnya yang tinggi ${ }^{11}$.

Termite hidup didalam sarang yang kokoh, sarang termite terbuat dari tanah liat, pasir, humus dan saliva rayap (berfungsi sebagai perekat), sehingga menghasilkan bangunan yang keras, cairan saliva ini diduga menjadi penyebab tumbuhnya jamur pada sarang ratu termite ${ }^{12}$. Sarang ratu termite Macrotermes gilvus Hagen. mengandung protein total 1,565\% (ekstrak aquabidest $0,175 \%$ dan sampel kering 1,39\%), kadar lemak sebesar 1,77\%, kadar abu sebesar 87,09\%, kadar Ca sebesar 0,411 \% dan kadar Posfor sebesar $0,147 \%{ }^{13}$.

Ekstrak etanol campuran termite Nasutitermes corniger dan sarangnya memiliki aktivitas sebagai agen antimikroba dan modulator bakteri resisten terhadap strain multidrug, dapat menghambat pertumbuhan Escherichia coli dan Staphylococcus aureus ${ }^{14}$. Ekstrak etanol dari termite Macrotermes obes Holmgren., Macrotermes estherae Desneux dan Odontotermes formosanus Shiraki. beserta sarangnya dapat menghambat pertumbuhan E. coli O157, E. coli JM 109, E. coli mos blue, dan E. coli BL21, Pseudomonas putida, Strataphoromoans bhaumini, dan Vibrio classical $^{15}$. Ekstrak heksan hasil freeze drying ratu termite Macrotermes gilvus Hagen. menghambat pertumbuhan Staphylococcus

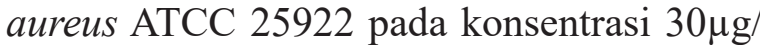
$\mu 1$ dan $15 \mu \mathrm{g} / \mu 1^{16}$.

Jamur yang hidup pada sarang ratu termite melakukan simbiosis dengan ratunya. Jamur memanfaatkan keadaan pada sarang untuk dapat bertahan hidup, sedangkan termite memanfaatkan jamur untuk membantu dalam menyediakan makanan dengan memecah selulosa dan lignin ${ }^{17}$. Pada sarang termite Reticulitermes lucifugus hidup beberapa jamur diantaranya Tricoderme viride, Mucor himeralis, Rhizopus nigricans, Aspergillus flavus, Alternaria sp, Penicylium verucosum dan Fusarium $s p^{18}$.

Peneliti terdahulu telah berhasil menapis 4 jenis jamur yang hidup pada sarang ratu termite Macrotermes gilvus Hagen., yaitu jamur Aspergillus flavus, Aspergillus niger, Mucor sp, dan Cladosporium $s p^{19}$. Jamur Aspergillus niger menghasilkan senyawa metabolit notasi AM-12-22-01, AM-12-6001, EG-13-31-2, EG-13-34-9, dan EG13-442. Kelima senyawa tersebut aktif terhadap Enterococcus faecalis ATCC 29212 dan Pseudomonas aeruginosa ATCC 2785320,21. Jamur Aspergillus flavus yang dibiakkan pada media Saboraud Dextrose Agar (SDA) 
menghasilkan senyawa metabolit golongan fenol, namun senyawa metabolit tersebut hanya terdapat pada ekstrak biakan pertama dan kedua dan berangsur hilang pada biakan berikutnya ${ }^{22}$.

Hilangnya senyawa metabolit jamur ini diduga karena perbedaan media tumbuh. Oleh karena itu pada penelitian ini dilakukan pengayaan media SDA dengan tanah sarang ratu termite yang bertujuan untuk mengetahui apakah senyawa metabolit golongan fenol dapat kembali terbentuk atau justru membentuk senyawa metabolit baru.

Sarang ditambahkan dalam beberapa konsentrasi, konsentrasi sarang yang memberikan pertumbuhan paling optimal akan digunakan untuk memperbanyak jamur, yang selanjutnya dapat dilakukan ekstraksi dan fraksinasi pada jamur untuk mengetahui senyawa metabolit sekunder yang dihasilkan dan menguji aktivitas antibiotiknya.

\section{Bahan dan Metode}

2.1. Alat

Laminar Air Flow (Biobase $\mathbb{R}$ ) BBS-V800), Autoklaf (All American ${ }^{\circledR}$ ), Magnetic stirer, Stirer (Iwaki ${ }^{\circledR}$ Stirer BS-46), Rotary evaporator (Buchi ${ }^{\circledR}$ Rotapor R-124), Labu rotary, Pipet mikro (Bench Mate ${ }^{\circledR}$ Digital micro pipette), Vortex (Iwaki ${ }^{\circledR}$ Mixer TM-151), Timbangan (Mettler ${ }^{\circledR}$ PM-200), Lemari pengering (oven) (Kirin $\left.{ }^{\circledR}\right)$, Kolom kromatografi, Bejana Kromatografi Lapis Tipis (KLT) (chamber), Plat KLT GF254 nm, detektor UV254nm, Hotplate, Jarum ose, Cawan petri (Diameter $=10 \mathrm{~cm})$.

\subsection{Bahan}

Isolat jamur A. flavus yang hidup pada sarang ratu termite Macrotermes gilvus Hagen., sarang ratu termite Macrotermes gilvus Hagen., Saboraud Dextrose Agar(SDA) (Merck $\left.{ }^{\circledR}\right)$, Nutrient Agar (NA) (Merck $\left.{ }^{\circledR}\right)$, Metanol, Aquadest, Etanol 70\%, Etil asetat, Kloroform, Natrium sulfat anhidrat, Dimetil sulfoksida (DMSO), Pereaksi FeCl3, Vanilin asam sulfat, Sitroborat, Dragendorff, Silika gel P 60 (0,863-0,260), Silika gel 60 PF254, $\mathrm{NaCl}$ fisiologis, Kloramfenikol, Ketokonazol, 12 bakteri uji (Bacillus subtilis, Enterococcus faecalis ATCC 29212, Eschericia coli ATCC 25922, Micrococcus luteus ATCC 10240, Pseudomonas aeruginosa ATCC 27853, Salmonella typhi, Salmonella typhimurium ATCC 14028, Salmonella typhosa NCTC 786, Staphylococcus aureus ATCC 6538, Staphylococcus epidermidis ATCC 12228, Streptococcus mutans ATCC 25175, Vibrio cholerae), dan 3 jamur uji (Candida albican, Aspergillus niger, Mucor sp.)

\subsection{Prosedur Percobaan}

2.3.1. Penyiapan Sampel Sarang Ratu Termite dan Pembuatan Media Diperkaya

Sampel sarang ratu termite Macrotermes gilvus Hagen. diambil di perkebunan kelapa sawit Silaut, Pesisir Selatan, Sumatera Barat. Sarang ratu termite digerus hingga halus lalu ditimbang sebanyak 0,$25 ; 0,50 ; 0,75$ dan $1 \mathrm{~g}$. Media dibuat dengan melarutkan 65 g serbuk SDA (Merck $\left.{ }^{\circledR}\right)$ dalam 1 liter air, dipanaskan sambil diaduk sampai terbentuk larutan yang jernih, kemudian ditambah perlahan serbuk sarang ratu termite, aduk hingga tersuspensi merata sehingga terbentuk media semi padat. Media diperkaya disterilkan dengan autoklaf (All American ${ }^{\circledR}$ ) pada suhu $121^{\circ} \mathrm{C}$ tekanan 30 atm selama 15 menit.

\subsubsection{Pembiakan Jamur}

Isolat jamur A. flavus sub-kultur biakan ketiga dari peneliti sebelumnya ${ }^{22}$ dibiakkan pada media diperkaya didalam cawan petri $(\mathrm{D}=10 \mathrm{~cm}, \mathrm{~V}=20 \mathrm{ml})$ yang akan menjadi biakan keempat. Sebagai kontrol, jamur dibiakkan pada media SDA. Satu jarum ose isolat yang diambil dari stok murni digoreskan pada permukaan media yang sudah ditambah sarang $(0,25 ; 0,50 ; 0,75$ dan $\mathrm{g} / \mathrm{mL})$, lalu diinkubasi pada suhu kamar selama 3 minggu.

\subsubsection{Metode Isolasi}

Sebanyak 25 cawan petri jamur $A$. flavus diekstraksi dengan cara maserasi menggunakan pelarut metanol sebanyak $3 \times 400 \mathrm{ml}$. Jamur dimaserasi dengan cara memasukkan sedikit pelarut metanol ke dalam cawan petri, diaduk perlahan sedemikian rupa supaya medium tidak terbawa, 
masukkan kedalam lumpang dan gerus, lalu dipindahkan ke dalam wadah maserasi (botol) dan ditambahkan metanol. Jamur dimaserasi didalam ruang gelap selama 3-5 hari sambil dikocok, lalu dilakukan penyaringan dan didapatkan ekstrak metanol jamur. Ekstrak metanol jamur diuapkan pelarutnya secara in-vacuo menggunakan rotary evaporator (Buchi ${ }^{\circledR}$ Rotapor R-124) sehingga didapatkan ekstrak kental metanol jamur. Sebanyak 0,952 g ekstrak kental metanol yang didapatkan kemudian dilarutkan dengan $100 \mathrm{ml}$ aquadest kemudian difraksinasi menggunakan etil asetat sebanyak 3 x $400 \mathrm{ml}$ menggunakan corong pisah, kemudian diuapkan in-vacuo sehingga diperoleh fraksi kental etil asetat dan fraksi sisa air.

Sebanyak 0,159 g fraksi etil asetat dikromatografi kolom menggunakan fase diam silika gel $60(0,063-0,200 \mathrm{~mm})$ dengan perbandingan jumlah sampel dan silika gel adalah 1:50, proses pengisian fase diam kedalam kolom dilakukan dengan cara basah, yaitu suspensi atau bubur silika gel dibuat terlebih dahulu dengan melarutkannya dengan n-eksan sampai fase diam terbentuk seperti bubur. Fase gerak yang digunakan adalah n-hexan:etil asetat (7:1), kloroform:metanol (9:1), dan metanol 100\%. Hasil kromatografi kolom ditampung dalam vial $5 \mathrm{ml}$ dan masing-masing eluat dimonitor dengan KLT menggunakan penampak noda lampu UV 254 $\mathrm{nm}$. Sub-fraksi dengan pola noda yang sama digabung dan diuapkan pelarutnya

\subsubsection{Pemantauan Senyawa Metabolit}

Sekunder dan Pemeriksaan Golongan Senyawa

Senyawa pada fraksi etil asetat dari masing-masing sub-kultur biakan jamur dianalisa dengan menggunakan kromatografi lapis tipis (KLT) untuk mengetahui apakah senyawa metabolit golongan fenol terbentuk kembali atau terbentuk senyawa metabolit baru. Pemantauan senyawa metabolit ini dilakukan dengan membandingkan penyebaran noda antara senyawa pada fraksi etil asetat jamur yang dibiakkan pada media diperkaya, ekstrak metanol jamur peneliti sebelumnya, dan fraksi etil asetat jamur yang dibiakkan pada media SDA saja. Digunakan eluen kloroform:metanol (9:1). Spot noda pada plat KLT dimonitor di bawah lampu UV $254 \mathrm{~nm}$ dan UV $365 \mathrm{~nm}$. Dihitung nilai Rf dari masing-masing spot noda.

$$
\begin{gathered}
\mathrm{Rf}=\text { Jarak yang ditempuh komponen } \\
\text { Jarak yang ditempuh pelarut }
\end{gathered}
$$

Pemeriksaaan golongan senyawa dilakukan dengan mereaksikan senyawa yang sudah dikembangkan pada Plat KLT GF254nm dengan pereaksi Dragendorf, vanillin asam sulfat, sitroborat, dan $\mathrm{FeCl} 3$.

\subsubsection{Uji Aktivitas Antibiotik}

Uji aktivitas dilakukan dengan metode difusi agar terhadap 12 bakteri dan 3 jamur uji. Ekstrak, fraksi dan sub-fraksi etil asetat, serta fraksi sisa dibuat dengan konsentrasi 10, 5, dan 2,5 mg/mL. Suspensi bakteri/jamur yang telah dibuat disapukan di permukaan media NA untuk bakteri dan media SDA untuk jamur, digerakkan ke kiri dan ke kanan serta memutar cawan Petri $90^{\circ}$. Selanjutnya $10 \mu \mathrm{L}$ larutan uji dipipet ke kertas cakram steril kemudian diletakkan sesuai dengan tanda pada cawan petri, diinkubasi selama 18-24 jam pada suhu $37^{\circ} \mathrm{C}$. Sebagai kontrol positif digunakan Kloramfenikol $1 \mathrm{mg} /$ $\mathrm{mL}$ untuk bakteri dan Ketokonazol $1 \mathrm{mg} /$ $\mathrm{mL}$ untuk jamur. Adanya aktivitas antibiotik dianalisis dengan mengukur diameter hambat bakteri pada kertas cakram.

\section{Hasil}

Jamur A. flavus secara visual memperlihatkan pertumbuhan yang optimal pada media SDA yang diperkaya sarang $1 \mathrm{~g} /$ mL (Gambar 1), konsentrasi media ini yang digunakan untuk memperbanyak jamur, jamur dibiakkan sebanyak 7 kali subkultur lanjutan, atau hingga subkultur biakan ke-sepuluh.

Kultivasi jamur A. flavus biakan kesepuluh sebanyak 25 petri diperoleh ekstrak kental metanol sebanyak 0,952 g (rendemen $18,58 \%$ ), fraksi kental etil asetat sebanyak $0,159 \mathrm{~g}$ (rendemen 16,70\%) dan fraki kental sisa sebanyak 0,754 g (rendemen 79,20 $\%)$. Penggunaan media diperkaya belum 


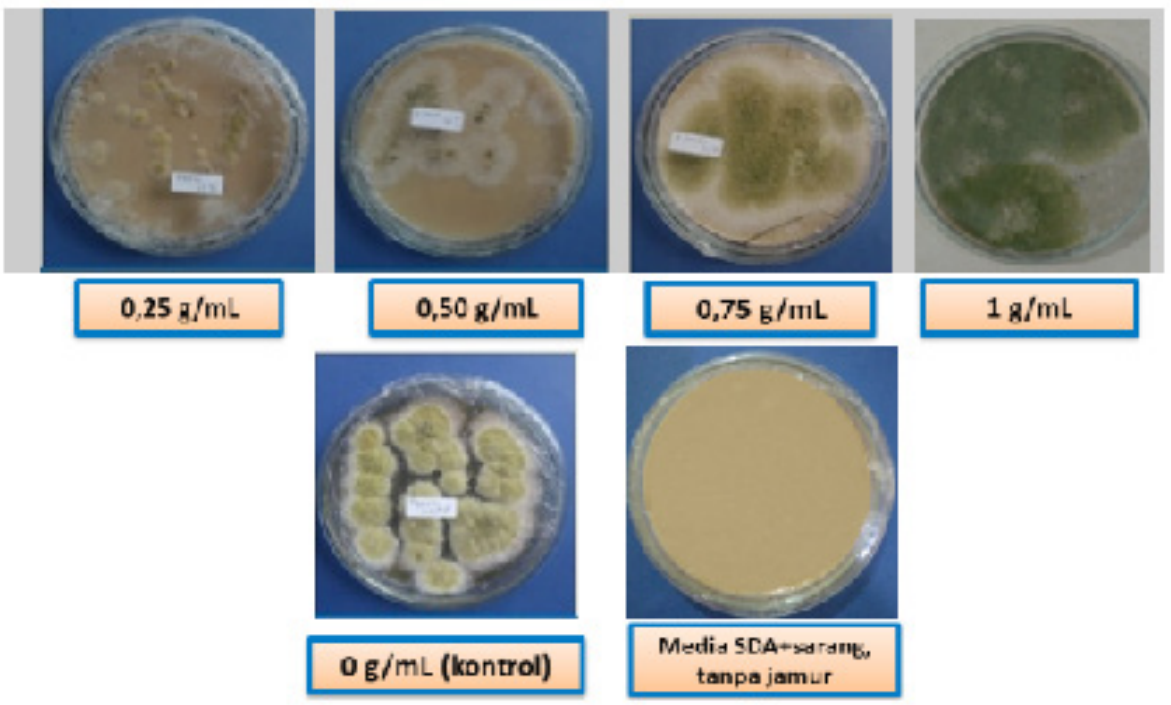

Gambar 1. Profil pertumbuhan isolat jamur A. flavus pada media SDA dengan berbagai penambahan sarang.

membentuk senyawa metabolit golongan fenol hingga jamur subkultur biakan kesepuluh, namun membentuk 6 spot noda baru pada fraksi etil asetat jamur $(\operatorname{Rf} 0.90,0,84,0,74$, $0,52,0,36$, dan 0,26). Spot noda 1,3, dan 5 (Rf $0,92,0,74$, dan 0,36 ) berfluoresensi dibawah sinar UV $365 \mathrm{~nm}$ (Gambar 2). Spot noda 1 (Rf $0,90)$ pada fraksi etil asetat jamur memiliki Rf yang sama dengan spot noda pada fraksi etil asetat sarang ratu termite (Gambar 3).

Ekstrak kental metanol jamur A. flavus memberikan daya hambat terhadap 4 bakteri uji, yaitu Pseudomonas aeruginosa ATCC 27853, Salmonella typhi, dan Vibrio cholera pada konsentrasi $10 \mathrm{mg} / \mathrm{mL}$, serta
Micrococcus luteus ATCC 10240 pada konsentrasi $5 \mathrm{mg} / \mathrm{mL}$ (Tabel 1). Ekstrak metanol jamur dengan konsentrasi $10 \mathrm{mg} / \mathrm{mL}$ tidak memberikan aktivitas terhadap 3 jamur uji dan 8 bakteri uji lainnya.

Fraksi etil asetat jamur A. flavus pada konsentrasi $5 \mathrm{mg} / \mathrm{mL}$ memberikan daya hambat terhadap pertumbuhan Micrococcus luteus ATCC 10240 dan Pseudomonas aeruginosa ATCC 27853 (Tabel 2). Fraksi sisa jamur A. flavus pada konsentrasi 10 $\mathrm{mg} / \mathrm{mL}$ memberikan daya hambat terhadap pertumbuhan Vibrio cholera dan Salmonella typhi (Tabel 3).

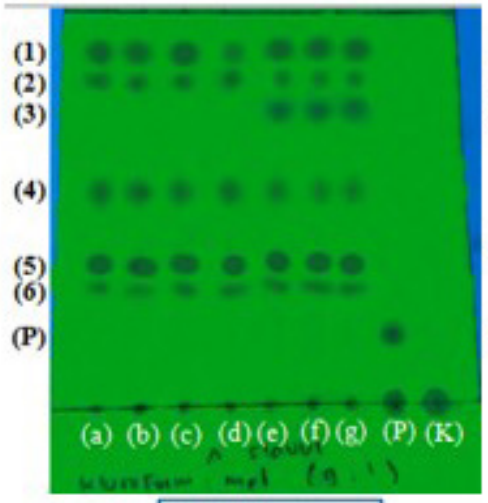

$\mathbf{U V}_{254 \mathrm{~nm}}$

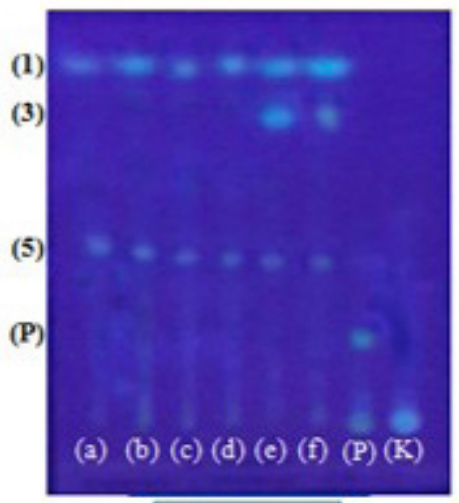

$\mathrm{UV}_{365 \mathrm{~nm}}$

Gambar 2. Profil KLT fraksi etil asetat jamur. Eluen kloroform:Metanol (9:1) (a).Jamur biakan 4 (b). Biakan 5 (c). Biakan 6 (d). Biakan 7 (e). Biakan 8 (f). Biakan 9 (g). Biakan 10 (P).Pembanding (sampel peneliti sebelumnya) (K).Kontrol (fraksi etil asetat jamur yang dibiakkan pada media SDA saja) 


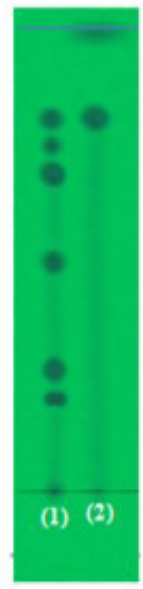

Gambar 3. Perbandingan Profil KLT (1). jamur A. flavus (2). Fraksi etil asetat sarang ratu termite. Eluen kloroform $100 \%$

Subfraksi notasi RA-13-14-2 dan RA13-14-3 pada konsentrasi $10 \mathrm{mg} / \mathrm{mL}$, serta subfraksi notasi RA-13-14-4 dan RA-13-149 pada konsentrasi $5 \mathrm{mg} / \mathrm{mL}$ memberikan aktivitas terhadap Pseudomonas aeruginosa ATCC 27853. Subfraksi notasi RA-13-14-5, RA-13-14-7 dan RA-13-14-8 padakonsentrasi $10 \mathrm{mg} / \mathrm{mL}$, serta subfraksi notasi RA-13-14-6 dan RA-13-14-9 pada konsentrasi $5 \mathrm{mg} / \mathrm{mL}$ memberikan aktivitas terhadap Micrococcus luteus ATCC 10240 (Tabel 4).

\section{Pembahasan}

Dari beberapa konsentrasi penambahan sarang ratu termite kedalam media SDA, secara visual terlihat jamur menghasilkan spora paling banyak dan memperlihatkan diameter koloni yang paling besar pada media SDA yang diperkaya sarang $1 \mathrm{~g} / \mathrm{mL}$.
Hal ini disebabkan karena semakin banyak sarang ratu termite yang ditambahkan maka unsur hara atau nutrisi yang didapatkan jamur untuk pertumbuhannya juga semakin banyak, sehingga pertumbuhannya bagus, namun media diperkaya mengalami keretakan apabila jumlah sarang yang ditambahkan melebihi $1 \mathrm{~g} /$ mL. Dengan kata lain, jamur $A$. flavus tumbuh optimal pada media SDA yang diperkaya sarang $1 \mathrm{~g} / \mathrm{mL}$. Pembiakan jamur dilakukan hingga beberapa tahap sub-kultur lanjutan karena pada pemantauan profil KLT fraksi etil asetat dari masing-masing biakan jamur menggunakan eluen kloroform:metanol (9:1) tidak memperlihatkan terbentuknya senyawa metabolit golongan fenol. Senyawa metabolit menghilang secara perlahan, diduga senyawa tersebut juga terbentuk kembali secara perlahan. Namun, hingga subkutur biakan kesepuluh senyawa metabolit golongan fenol tidak kembali terbentuk. Disisi lain terbentuk 6 spot noda baru pada fraksi etil asetat jamur.

Satu strain jamur dapat menghasilkan senyawa yang berbeda-beda apabila media tumbuhnya berbeda atau dikenal dengan istilah OSMAC (One strain many compounds). Perubahan komposisi media, kultivasi dan penambahan enzim dapat mempengaruhi senyawa metabolit yang dihasilkan. Seperti pada jamur Streptomyces $s p$, yang menghasilkan 14 senyawa lebih banyak ketika media tumbuhnya diperkaya menggunakan $\mathrm{CaCo}_{3}$ dan $\mathrm{Al}_{2} \mathrm{O}$. Sedangkan jamur Nigospora sp MA75, ketika dibiakkan pada 3 media yang berbeda menghasilkan senyawa yang berbeda pada masing-masing

Tabel 1. Data diameter hambat ekstrak metanol jamur A. flavus terhadap bakteri uji

\begin{tabular}{cccccc}
\hline Bakteri uji & $\begin{array}{c}(+) \\
\text { Kloramfenikol }\end{array}$ & $(10 \mathrm{mg} / \mathrm{mL})$ & $(5 \mathrm{mg} / \mathrm{mL})$ & $(2,5 \mathrm{mg} / \mathrm{mL})$ & $\begin{array}{c}(-) \\
\text { DMSO }\end{array}$ \\
\hline $\begin{array}{c}\text { Pseudomonas aeruginosa } \\
\text { ATCC 27853 }\end{array}$ & $21,41 \pm 0,64 \mathrm{~mm}$ & $6,25 \pm 0,32 \mathrm{~mm}$ & - & - \\
Vibrio cholerae & $23,18 \pm 0,40 \mathrm{~mm}$ & $7,42 \pm 0,67 \mathrm{~mm}$ & - & - \\
Salmonella typhi \\
$\begin{array}{c}\text { Micrococcus } \\
\text { luteus }\end{array}$ \\
ATCC 10240
\end{tabular}

*Diameter hambat yang tertera pada tabel belum dikurangi dengan diameter cakram $(5 \mathrm{~mm})$ 
Tabel 2. Data diameter hambat fraksi etil asetat $\boldsymbol{A}$. flavus terhadap bakteri uji

\begin{tabular}{|c|c|c|c|c|c|}
\hline Bakteri uji & $\begin{array}{l}(+) \\
\text { Kloramfenikol }\end{array}$ & $(10 \mathrm{mg} / \mathrm{mL})$ & $(5 \mathrm{mg} / \mathrm{mL})$ & $(2,5 \mathrm{mg} / \mathrm{mL})$ & $\begin{array}{c}(-) \\
\text { DMSO }\end{array}$ \\
\hline $\begin{array}{c}\text { Pseudomonas aeruginosa } \\
\text { ATCC } 27853\end{array}$ & $22,13 \pm 0,75 \mathrm{~mm}$ & $7,25 \pm 0,34 \mathrm{~mm}$ & $\begin{array}{c}6,55 \pm 0,58 \\
\mathrm{~mm}\end{array}$ & - & - \\
\hline $\begin{array}{l}\text { Micrococcus luteus } \\
\text { ATCC } 10240\end{array}$ & $21,62 \pm 0,69 \mathrm{~mm}$ & $8,71 \pm 0,80 \mathrm{~mm}$ & $\begin{array}{c}7,22 \pm 0,36 \\
\mathrm{~mm}\end{array}$ & - & - \\
\hline Vibrio cholerae & $21,03 \pm 0,67 \mathrm{~mm}$ & - & - & - & - \\
\hline Salmonella typhi & $21,74 \pm 0,39 \mathrm{~mm}$ & - & - & - & - \\
\hline
\end{tabular}

biakan. Pengayaan media SDA dengan sarang termite membentuk 6 spot noda baru pada fraksi etil asetat jamur, hal ini sesuai dengan pendekatan OSMAC ${ }^{23}$.

Spot noda 1 (Rf 0,90) pada fraksi etil asetat jamur memiliki Rf yang sama dengan spot noda pada fraksi etil asetat sarang ratu ermite Hal ini menunjukkan bahwa noda tersebut merupakan senyawa yang terdapat pada sarang termite yang ikut terekstraksi. Media ikut terbawa dan terekstrak karena teksturnya yang lunak.

Pengayaan media SDA dengan sarang ratu termite membentuk senyawa metabolit sekunder yang berbeda pada jamur Aspergillus flavus, berdasarkan pendekatan OSMAC hal ini disebababkan karena perbedaan nutrisi atau unsur hara yang didapatkan oleh jamur A. flavus. Unsur hara yang terdapat pada media SDA yaitu berupa glukosa dan pepton, sedangkan pada media SDA yang diperkaya sarang ratu termite selain terdapat glukosa dan pepton juga terdapat unsur hara lain seperti protein, lemak, kalsium, fosfor, natrium, kalium, magnesium, dan fosfat.

Berdasarkan reaksi kimia dengan reagen penampak noda, keenam spot noda memberikan hasil negatif terhadap reagen $\mathrm{FeCl}_{3}$, Dragendorff, dan sitroborat, disisi lain keenam spot noda memberikan warna merahungu pada plat KLT setelah disemprot dengan reagen vanilin asam sulfat dan dipanaskan. Hal ini menunjukkan bahwa keenam spot noda tersebut merupakan senyawa golongan terpenoid. Ekstrak metanol sarang ratu termite Macrotermes gilvus Hagen. mengandung senyawa salah satunya golongan terpenoid ${ }^{24}$. Metabolit sekunder golongan terpenoid yang dihasilkan oleh jamur A. flavus lain adalah senyawa ophiobolins yang termasuk kedalam golongan sesterterpen ${ }^{25}$.

Metabolit sekunder lain yang dihasilkan A. flavus pada habitat lain diantaranya Aflatoxin, Sterigmatocystin, Asam siklopiazonik, Asam kojik, Asam $\beta$-nitropropionik, Aspertoxin, Aflatrem, Gliotoxin dan Asam aspergillik, serta Dihydroxyaflavinine, Indole, Paspalinine dan Versicolorin $\mathrm{A}^{26}$ Pengaruh kondisi lingkungan adalah parameter yang mempengaruhii pertumbuhan dan produksi metabolit bioaktif jamur ${ }^{27}$.

Tabel 3. Data diameter hambat fraksi sisa $\boldsymbol{A}$. flavus terhadap bakteri uji

\begin{tabular}{|c|c|c|c|c|c|}
\hline Bakteri uji & $\stackrel{(+)}{\text { Kloramfenikol }}$ & $(10 \mathrm{mg} / \mathrm{mL})$ & $(5 \mathrm{mg} / \mathrm{mL})$ & $(2,5 \mathrm{mg} / \mathrm{mL})$ & $\begin{array}{c}(-) \\
\text { DMSO }\end{array}$ \\
\hline $\begin{array}{c}\text { Pseudomonas aeruginosa } \\
\text { ATCC } 27853\end{array}$ & $22,53 \pm 0,28 \mathrm{~mm}$ & - & - & - & - \\
\hline $\begin{array}{c}\text { Micrococcus luteus } \\
\text { ATCC } 10240\end{array}$ & $21,86, \pm 0,57 \mathrm{~mm}$ & - & - & - & - \\
\hline Vibrio cholerae & $23,22 \pm 0,50 \mathrm{~mm}$ & $6,84 \pm 0,63 \mathrm{~mm}$ & - & - & - \\
\hline Salmonella typhi & $23,14 \pm 0,31 \mathrm{~mm}$ & $6,69 \pm 0,19 \mathrm{~mm}$ & & & \\
\hline
\end{tabular}

*Diameter hambat yang tertera pada tabel belum dikurangi dengan diameter cakram $(5 \mathrm{~mm})$ 
Tabel 4. Data diameter hambat sub-fraksi etil asetat A. flavus terhadap bakteri uji

\begin{tabular}{|c|c|c|c|c|c|c|c|}
\hline \multirow[t]{3}{*}{ No } & \multirow[t]{3}{*}{ Subfraksi } & \multicolumn{6}{|c|}{ Konsentrasi Hambat Bakteri } \\
\hline & & \multicolumn{3}{|c|}{$\begin{array}{c}\text { Pseudomonas aeruginosa } \\
\text { ATCC } 27853\end{array}$} & \multicolumn{3}{|c|}{$\begin{array}{c}\text { Micrococcus luteus } \\
\text { ATCC } 10240 \\
\end{array}$} \\
\hline & & $(10 \mathrm{mg} / \mathrm{mL})$ & $(5 \mathrm{mg} / \mathrm{mL})$ & $\begin{array}{c}(2,5 \\
\mathrm{mg} / \mathrm{mL})\end{array}$ & $(10 \mathrm{mg} / \mathrm{mL})$ & $(5 \mathrm{mg} / \mathrm{mL})$ & $\begin{array}{c}(2,5 \\
\mathrm{mg} / \mathrm{mL})\end{array}$ \\
\hline $\mathbf{l}$ & RA-13-14-1 & - & - & - & - & - & - \\
\hline 2 & RA-13-14-2 & $7,70 \pm 0,54 \mathrm{~mm}$ & - & - & - & - & - \\
\hline 3 & RA-13-14-3 & $7,66 \pm 0,57 \mathrm{~mm}$ & - & - & - & - & - \\
\hline 4 & RA-13-14-4 & $7,59 \pm 0,82 \mathrm{~mm}$ & $6,43 \pm 0,10 \mathrm{~mm}$ & - & - & - & - \\
\hline 5 & RA-13-14-5 & - & - & - & $7,70=0,74 \mathrm{~mm}$ & - & - \\
\hline 6 & RA-13-14-6 & - & - & - & $8,13 \pm 0,47 \mathrm{~mm}$ & $7,63 \pm 0,6 \mathrm{~mm}$ & - \\
\hline 7 & RA-13-14-7 & - & - & - & $6,47 \pm 0,29 \mathrm{~mm}$ & - & - \\
\hline 8 & RA-13-14-8 & - & - & - & $6,90 \pm 0,88 \mathrm{~mm}$ & - & - \\
\hline 9 & RA-13-14-9 & $7,54 \pm 0,38 \mathrm{~mm}$ & $6,37 \pm 0,70 \mathrm{~mm}$ & - & $7,59 \pm 0,69 \mathrm{~mm}$ & $6,41 \pm 0,3 \mathrm{~mm}$ & - \\
\hline 10 & RA-13-14-10 & - & - & - & - & - & - \\
\hline
\end{tabular}

*Diameter hambat yang tertera pada tabel belum dikurangi dengan diameter cakram $(5 \mathrm{~mm})$

Pengujian aktivitas antibiotik dilakukan dengan metode difusi. Prinsip dasar dari metode ini adalah pengukuran luas zona bening atau daerah hambatan pertumbuhan mikroba karena berdifusinya sampel dari titik awal pemberian ke daerah difusi ${ }^{28}$. Aktivitas antibiotik dikategorikan memiliki sensitifitas tinggi apabila diameter zona bening $>20 \mathrm{~mm}$, sensitifitas sedang bila diameter zona bening berkisar antara 15-19 $\mathrm{mm}$, dan sensitifitas rendah bila diameter zona bening $<14 \mathrm{~mm}^{29}$. Aktivitas antibakteri dari ekstrak metanol, fraksi dan sub-fraksi etil asetat, serta fraksi sisa bersifat rendah karena memiliki diameter hambat $<14 \mathrm{~mm}$ dan bersifat bakteriostatik karena hanya dapat menghambat pertumbuhan bakteri tidak membunuhnya. Hal ini terlihat dari zona bening sekeliling cakram, setelah lebih dari 24 jam tidak ada lagi zona bening.
Kloramfenikol dikatakan resisten apabila diameter hambat pertumbuhan bakteri yang dihasilkan $<20 \mathrm{~mm}$ dan sensitif apabila hasil diameter hambat $>21 \mathrm{~mm}^{30}$. Diameter hambat Kloramfenikol terhadap bakteri uji dalam penelitian ini berkisar antara 21-23 mm. Hal ini menunjukkan bahwa Kloramfenikol yang digunakan bersifat sensitif terhadap bakteri uji.

Pemisahan fraksi etil asetat menggunakan kromatografi kolom didapatkan 10 sub-fraksi. Dari analisa terhadap hasil uji aktivitas antibakteri terhadap 10 sub-fraksi (Tabel 4) menunjukkan bahwa spot noda 2, 5, dan 6 pada fraksi etil asetat (Rf 0,84; $0,36 ; 0,26)$ memberikan aktivitas antibakteri terhadap Pseudomonas aeruginosa ATCC 27853 pada konsentrasi $50 \mu \mathrm{g} /$ disk, sedangkan spot noda 3 dan $4(\operatorname{Rf} 0,74 ; 0,52)$ memberikan

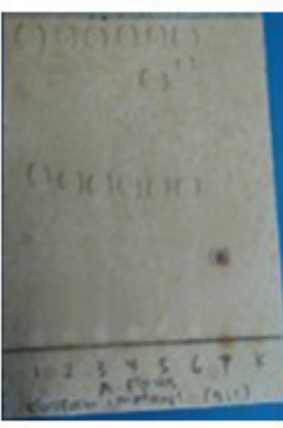

Reagen FeCl3
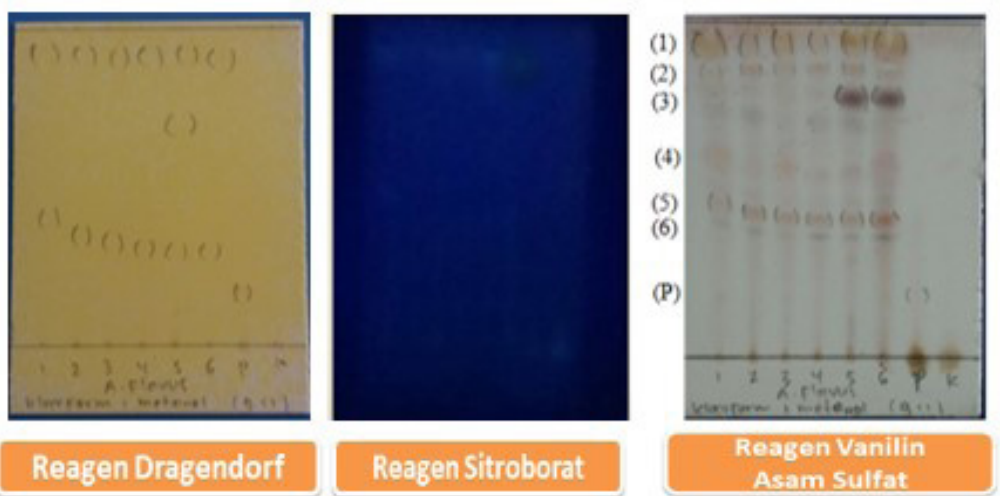

Gambar 4. Profil KLT fraksi etil asetat masing-masing biakan jamur $\boldsymbol{A}$. flavus dengan penampak noda 


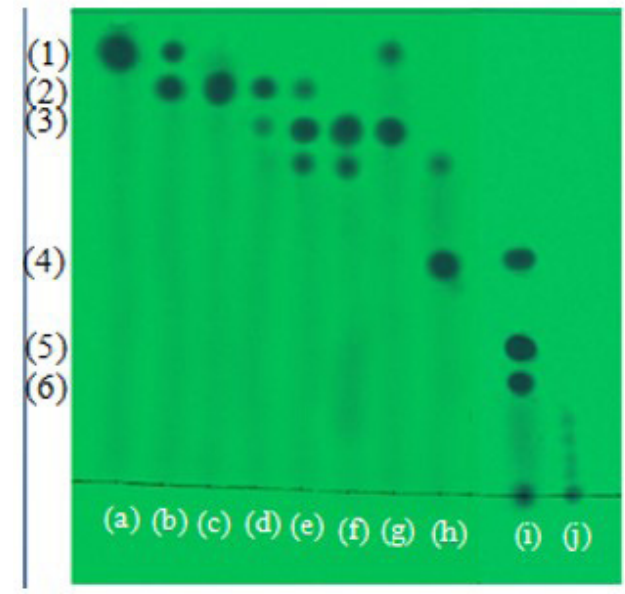

Gambar 5. Profil KLT sub-fraksi etil asetat jamur A. flavus. Eluen kloroform : Metanol (9:1) (a).Subfraksi notasi RA-13-14-1 (b).Notasi RA-13-14-2 (c).Notasi RA-13-14-3 (d).Notasi RA-13-14-4 (e). Notasi RA-13-14-5 (f).Notasi RA-13-14-6 (g).Notasi RA-13-14-7. (h).Notasi RA-13-14-8. (i).Notasi RA-13-14-9. (j).Notasi RA-13-14-10.

aktivitas antibakteri terhadap Micrococcus

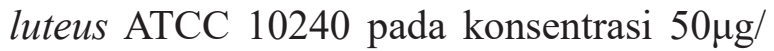
disk.

Daya hambat yang diberikan ekstrak metanol, fraksi dan sub-fraksi etil asetat diduga karena adanya senyawa terpenoid. Mekanisme terpenoid sebagai antibakteri adalah bereaksi dengan porin (protein transmembran) pada membran luar dinding sel bakteri, membentuk ikatan polimer yang kuat sehingga mengakibatkan rusaknya porin. Rusaknya porin yang merupakan pintu keluar masuknya senyawa akan mengurangi permeabilitas dinding sel bakteri yang akan mengakibatkan sel bakteri akan kekurangan nutrisi, sehingga pertumbuhan bakteri terhambat atau mati ${ }^{31}$.

Jamur $A$. flavus lain yang diisolasi dari tanah menghasilkan aflatoksin. $50 \mu$ laflatoksin ini menunjukkan aktivitas antibakteri terhadap Escherichia coli, Micrococcus luteus, Staphylococcus aureus dan Proteus mirabilis dengan zona hambat berturut-turut $17,22,12$ dan $21 \mathrm{~mm}^{32}$.

Hal ini menunjukkan bahwa aktivitas antibakteri yang dimiliki $A$. flavus yang hidup pada sarang ratu termite Macrotermes gilvus Hagen. berbeda dengan A. flavus lain, karena perbedaan habitat mempengaruhi senyawa metabolit sekunder yang dihasilkan.

\section{Simpulan}

Jamur Aspergillus flavus pada media diperkaya hingga sub-kultur biakan kesepuluh belum membentuk senyawa metabolit awal, namun membentuk 6 spot noda senyawa metabolit yang merupakan golongan terpenoid.

Spot noda 2,5,6 (Rf 0,84; 0,36; 0,26) memiliki daya hambat terhadap Pseudomonas aeruginosa ATCC 27853. Spot noda 3,4 (Rf $0,74 ; 0,52)$ memiliki daya hambat terhadap Micrococcus luteus ATCC 10240.

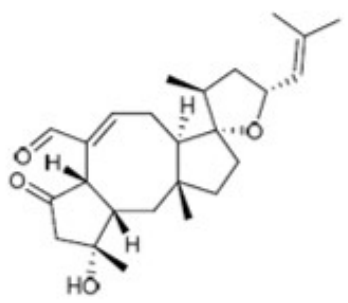

Gambar 6. Struktur ophiobolins $\mathrm{s}^{25}$ 
Aktivitas antibakteri dari A. flavus yang hidup pada sarang ratu termite Macrotermes gilvus hagen bersifat rendah dan bakteriostatik.

\section{Daftar Pustaka}

1. Astuti. Identifikasi, Sebaran dan Derajat Kerusakan Kayu oleh Serangan Rayap Coptotermes (Isoptera: Rhinotermitidae) di Sulawesi Selatan. [Disertasi]. Makassar: Universitas Hasanuddin; 2013.

2. Arifin Z, Dahlan Z, Sabaruddin, Irsan C, Hartono Y. Characteristics, Morphometry and Spatial Distribution of Populations of Subterranean Termites Macrotermes Gilvus Hagen., (Isoptera: Termitidae) in the Rubber Plantation Land Habitat Which Managed Without Pesticides and Chemical Fertilizers. Int J. Sci. Res. 2014;3(4);102-6.

3. Alen Y, Suci LN, Suarmin O, Suharti S, Larasati A, Suparman A, et al. Primary Metabolites Analysis of Termite Queen (Macrotermes gilvus Hagen.) and Burn Healing Assay. Abstract Paper of The Conference on Advancing the Life Science and Public Health Awrence. July 10-11. Nagoya, Japan. 2016a.

4. Alen Y, Suci LN, Suarmin O, Rivai H. Analisis of Amino Acid Levels of Freeze Dried Termite Queen Macrotermes gilvus Hagen. International journal of indigenous Herb and drug. 2017e;2(3):15.

5. Alen Y, Suci LN, Suarmin O, Rivai H. Analysis of Fatty Acids Levels of Freeze Dried Termite Queen Macrotermes gilvus Hagen. using gas chromatography-mass spectrometry. International journal of indigenous Herb and drug. 2017b;2(4):14.

6. Alen Y, Suarmin O, Suci LN, Kurniawan R, Yasardi F, Ramadhani V. Analysis Levels of Fatty Acids from Freezedried Termite Queen Macrotermes gilvus Hagen., using GC-MS and Antihyperlipidemia Test. Abstract Paper of The Conference on Advancing the Life Science and Public Health Awrence. July 10-11. Nagoya, Japan. 2016b.

7. Alen Y. Ratu Termite Macrotermes gilvus
Hagen.: Kajian Awal Saintifik dalam Pandangan Farmasi. Abstrak Seminar Nasional dan Workshop Perkembangan Terkini Sains Farmasi dan Klinik 6. 2324 September. Padang. 2016a.

8. Alen Y, Damris M, Putri D, Almahdy. Kajian Praklinik Serta Potensi Freeze Drying Ratu Rayap Macrotermes gilvus Hagen. Sebagai Kandidat Obat Herbal Dalam Sediaan Kapsul. Abstrak Seminar Nasional POKJANAS TOI ke-52. 12-13 April. Stifar Riau. 2017b.

9. Alen Y, R Rahmawati, Aldi Y, T Nitoda, N Baba, S Nakajima. Immunomodulatory Activity of Freeze Dried Termite Queen Macrotermes gilvus Hagen. Abstrak Paper of The Conference on Advancing the Life Science and Public Health Awareness. July 10-11. Nagoya, Japan. 2016d.

10. Alen Y, Indraini RA, Yuliandra Y. Toksisitas Akut dan Sub-akut Freeze Drying Ratu Anai-anai (Macrotermes gilvus Hagen.) terhadap Fungsi Hati Mencit. Abstrak Seminar Nasional dan Workshop Perkembangan Terkini Sains Farmasi dan Klinik 6. 23-24 September. Padang. 2016e.

11. Adepoju OT, Omotayo OA. Nutrient Composition and Potential Contribution of Winged Termites (Macrotermes bellicosus Smeathman.) to Micronutrient Intake of Consumers in Nigeria. Br. J. Appl. Sci. Technol. 2014;4(7);1149-58.

12. Subekti N. Kandungan Bahan Organik dan Akumulasi Mineral Tanah pada Bangunan Sarang Rayap Tanah Macrotermes Gilvus Hagen. (Blattodea: Termitidae). Biosaintifika Berkala Ilmiah Biologi. 2012a;4(1);10-7.

13. Alen Y, Okta FN, Rusdian R, Agresa FL, Marcelina S, Fitri AM. Analisis Metabolit Primer Sarang Ratu Termite Macrotermes gilvus Hagen. dari Kebun Sawit MukoMuko Bengkulu. Abstrak Paper dan Prosiding Seminar Nasional dan Workshop Perkembangan Terkini Sains Farmasi dan Klinik 5. 6-7 November. Padang. 2015a.

14. Chaves TP, Clementino ELC, Felismino DC, Alves RRN, Vasconcellos A, 
Coutinho HDM, Medeiros ACD. Antibiotic Resistance Modulation by Natural Products Obtained from Nasutitermes corniger (Motschulsky, 1855 ) and Its Nest. Saudi J. Biol. Sci. 2015;22;404-8.

15. Solavan A, Paulmurugan R, Wilsanan V. Antibacterial Activity of Subterranian Termites Used in South Indian Folk Medicine. Indian Journal of Traditional Knowledge. 2007;6(4);559-62.

16. Alen Y, Putri D, Damris M, Putri SFR, Dwithania M, Suharti N. Uji Antibakteri Freeze Drying Ratu Rayap Macrotermes gilvus Hagen. Abstrak Seminar Nasional POKJANAS TOI ke-52. 12-13 April. Padang. 2017d.

17. Mathew GM, Ju YM, Lai CY, Mathew DC, Huang CC. Microbial Community Analysis in The Termite Gut and Fungus Comb of Odontotermes formosanus: The Implication of Bacillus as Mutualists. FEMS Microbiol Ecol. 2012;79;504-17.

18. Wójcik A, Andres B. Mildew Fungi Found in Termites (Reticulitermes lucifugus) and Their Nests. Journal of Entomological and Acarological Research. 2015;47;2184.

19. Alen Y, Sari MP, Putra DP. Penapisan Jamur dari Sarang Termite (Macrotermes gilvus Hagen.) dan Uji Aktivitas AntiJamur. Abstrak Paper dan Prosiding Seminar Nasional dan Workshop Perkembangan Terkini Sains Farmasi dan Klinik 5. 6-7 November . Padang. 2015 b.

20. Alen Y, Melati A, Djamaan A. Isolasi Senyawa Antibiotika Jamur Aspergilus niger Simbiotik Sarang Ratu Anai- anai Macrotermes gilvus Hagen. Abstrak Seminar Nasional dan Workshop Perkembangan Terkini Sains Farmasi dan Klinik 6. 23 - 24 September. Padang. $2016 f$.

21. Alen, Y, Guslianti E, Suharti, N. Isolation and Activity Assay of Secondary Metabolites of Aspergilus niger In-Habiting in Queen Termite's Nest Macrotermes gilvus Hagen., On Sabouraud Dextrose Agar(SDA) Enriched Medis. Abstrak Paper Of International Conference On Interdisciplinarity In
Natural Drugs Research (ICIND. Andalas University, Padang. 29-30 August. 2017d

22. Alen Y, Sarina G, Djamaan A. Isolasi Senyawa Mayor Metabolit Sekunder Jamur Aspergilus flavus Simbiotik Sarang Ratu Anai-anai (Macrotermes gilvus Hagen.). Abstrak Seminar Nasional dan Workshop Perkembangan Terkini Sains Farmasi dan Klinik 6. 23 - 24 September. Padang. 2016g.

23. Wei $\mathrm{H}$, Lin $\mathrm{Z}$, Li $\mathrm{D}, \mathrm{Gu}$ Q, Zhu T. OSMAC (One Strain Many Compounds) Approach in The Research of Microbial Metabolites-A review. Acta Microbiol. Sin. 2010;50(6);01-9.

24. Alen Y, Afnillia F, Rustini. Uji Antibakteri Metabolit Sekunder Ekstrak Metanol Sarang Ratu Termite Macrotermes gilvus Hagen. Abstrak Seminar Nasional POKJANAS TOI ke-52. 12-13 April. Stifar Riau. 2017e.

25. Bladt TT, Frisvad JC, Knudsen PB, Larsen TO. Anticancer and Antifungal Compounds From Aspergillus, Penicillium and Other Filamentous Fungi. Molecules. 2013;18;11338-76.

26. Hedayati MT, Pasquolotta AC, Warn PA, Bowyer P, Denning DW. Aspergillus flavus: Human Phatogen, Allergen and Mycotoxin Producer. Microbiology .2007;153;1677-92.

27. Kalyani P, Geetha S, Hemalatha KPJ. Optimization of Cultural Conditions for Improved Production and Bioactive Metabolites By Aspergillus niger (MTCC-961). Eur J Pharm Med Res. 2016;3(10);255-60.

28. Choma IM, Grzelak EM..Biautography Detection in Thin-Layer Chromatography. J. Chromatogr. A. 2010;1-8.

29. Cockerill FR, Wikler MA, Alder J, Dudley MN, Eliopoulos GM, Ferraro MJ, Hardy DJ, Hecht DW. Performance Standarts for Antimicrobial Disk Susceptibility Tests; Approved Standart-Eleventh Edition. Clinical and Laboratory Standart Institute. 2012;32(1);1-58.

30. Andrews JM, Howe RA. BSAC Standardized Disc Suspetibility Testing Method (version 10). Journal Antimicrob 
Chemotheraphy. 2011;66;2726-57.

31. Cowan MM. Plant Products As Antimicrobial Agents. Clinical Microbiology Reviews. 1999;12(4);564582.

32. 32. Praveena YSN, Padmini PPC. Antibacterial Activities of Micotoxins from Newly Isolated Filamentous Fungi. International Journal of Plant, Animal and Enviromental Sciences. 2011;1(1):;8-13. 